\title{
Portland blended cements: demolition ceramic waste management
}

\author{
M.A. Trezza $\bowtie$, S. Zito, A. Tironi, E.F. Irassar, V.F. Rahhal \\ Facultad de Ingeniería, CIFICEN (CONICET -UNCPBA), (Buenos Aires, Argentina). \\ $\triangle$ mtrezza@fio.unicen.edu.ar
}

\author{
Received 13 January 2016 \\ Accepted 21 July 2016 \\ Available on line 23 January 2017
}

\begin{abstract}
Demolition ceramic wastes (DCWs) were investigated in order to determine their potential use as supplementary cementitious materials in Portland Blended Cements (PBCs). For this purpose, three ceramic wastes were investigated. After characterization of the materials used, the effect of ceramic waste replacement (8, 24 and $40 \%$ by mass) was analyzed. Pozzolanic activity, hydration progress, workability and compressive strength were determined at 2, 7 and 28 days. The results showed that the ground wastes behave as filler at an early age, but as hydration progresses, the pozzolanic activity of ceramic waste contributes to the strength requirement.
\end{abstract}

KEYWORDS: Portland cement; Demolition ceramic waste; Pozzolane; Characterization

Citation/Citar como: Trezza, M.A.; Zito, S.; Tironi, A.; Irassar, E.F.; Rahhal, V.F. (2017) Portland blended cements: demolition ceramic waste management. Mater. Construcc. 67 [325], e114. http://dx.doi.org/10.3989/mc.2017.00516

RESUMEN: Cementos Portland con adiciones: manejo de residuos cerámicos de demolición. Se estudiaron residuos cerámicos de demolición (DCWs) a fin de determinar su potencial uso como materiales cementicios suplementarios en cementos mezcla (PBC). Para este propósito, se investigaron tres residuos cerámicos. Luego de la caracterización de los materiales a utilizar, se analizó el efecto del reemplazo por residuos cerámico $(8,24$ y $40 \%$ en peso). Se estudió la actividad puzolánica, el progreso de la hidratación, la trabajabilidad y la resistencia a compresión a 2, 7 y 28 días. Los resultados mostraron que los residuos molidos se comportaron como fillers a edades tempranas, pero con el progreso de la hidratación, la actividad puzolánica de los residuos cerámicos contribuye a los requerimientos de resistencia.

PALABRAS CLAVE: Cemento Portland; Resíduos cerámicos de demolición; Puzolana; Caracterización

ORCID ID: M.A. Trezza (http://orcid.org/0000-0002-4193-0066); S. Zito (http://orcid.org/0000-0002-7356-8612); A. Tironi (http://orcid.org/0000-0002-2821-2043); E.F. Irassar (http://orcid.org/0000-0003-4488-0014); V.F. Rahhal (http://orcid.org/0000-0001-7710-1203)

Copyright: (C) 2017 CSIC. This is an open-access article distributed under the terms of the Creative Commons Attribution License (CC BY) Spain 3.0.

\section{INTRODUCTION}

Currently, environmental concern and energy reduction have become two major topics under discussion. Portland cement (PC) industry does not remain unaware of these topics and many changes have occurred in the last decades, one of which promotes the use of natural materials, waste and industrial by-products in its manufacturing process. Consequently, energy demand in clinker production has been significantly reduced over the last years.
The raw materials for clinker production are primarily based on limestone, clay or its natural mixture. In many cases, alternative raw materials are mostly used as corrective materials (1). Typical examples are fly ash, calcium fluoride, sludge, etc. The future challenge of the cement industry is to use more alternative raw materials originated as byproducts from other industries or directly from other waste streams. Regarding resource efficiency along the value chain, concrete recycling as coarse aggregate source is already in an advanced state (1). 
On the other hand, the most efficient alternative for Portland cement materials replacement is pozzolans such as calcined clays. ASTM C618 (2) defines a pozzolan as " $a$ siliceous or siliceous and aluminous material which, in itself, possesses little or no cementitious value but which will, in finely divided form in the presence of moisture, react chemically with calcium hydroxide at ordinary temperature to form compounds possessing cementitious properties".

Clay minerals in their natural state, due to their crystalline structure will not have pozzolanic properties. However, they have good pozzolanic activity when calcined at temperatures between 600 and $900{ }^{\circ} \mathrm{C}$ and ground to cement fineness $(3,4)$. The ceramic industry generates a large volume of calcined clay wastes (up to $3 \%$ of production depending on producer and country). These products, discarded as scrap, are generally crushed to be used as aggregate or as landscaping material, reducing the volume available. Nevertheless, another more interesting source is demolition scraps where ceramic materials are the largest components due to the traditional building habits and old-line production technology in Argentina.

Construction and Demolition (C\&D) wastes contribute to the largest volume of wastes worldwide $(75 \%)$, and ceramic materials contribute to the highest percentage of wastes within the $\mathrm{C} \& \mathrm{D}$ wastes $(54 \%)(5)$.

These $\mathrm{C} \& \mathrm{D}$ wastes are mainly composed $(75 \%)$ by bricks, slabs, tiles, ceramic floors and other materials as concrete and lime and / or cement mortar (6).

In recent years, the literature on construction and demolition waste management has grown $(7,8)$.
Construction waste, or $\mathrm{C} \& \mathrm{D}$ waste, is generally defined as a mixture of inert and non-inert materials arising from construction, excavation, renovation, demolition, roadwork and other constructionrelated activities (9).

Some proposals promote the use of waste from the ceramic industry, which has already gone through a process at high temperature, particularly waste from roof tiles (10-15), bricks (16-19) and floors tiles (20) as pozzolan. It is worth classifying this waste in terms of its potential as active pozzolanic capability and Portland cement additions.

In this study, three demolition ceramic wastes (DCWs) originated in different industrial processes were characterized and the potential pozzolanic activity was determined in order to investigate the potential use of ground DCWs as supplementary cementitious materials in Portland Blended Cements (PBC).

\section{EXPERIMENTAL PROCEDURE}

\subsection{Materials}

Portland cement (IRAM 50000) (21) was used to prepare paste and mortar specimens. This cement is equivalent to CEM I of EN 197:1(22) containing up to $5 \%$ of limestone filler as minor constituent. The chemical composition was provided by the producer and the mineralogical composition was calculated by Bogue's formulas based on clinker chemical composition. The specific gravity and Blaine fineness are 3.14 and $315 \mathrm{~m}^{2} / \mathrm{kg}$, respectively (Table 1).

TABLE 1. Chemical and mineralogical composition of materials

\begin{tabular}{|c|c|c|c|c|}
\hline \multirow[b]{2}{*}{ Parameters } & \multirow[b]{2}{*}{ Pórtland cement (PC) } & \multicolumn{3}{|c|}{ Ceramic wastes } \\
\hline & & $\begin{array}{l}\text { Industrial Ceramic } \\
\text { Block (CB) }\end{array}$ & $\begin{array}{l}\text { Mud Brick } \\
\text { (MB) }\end{array}$ & $\begin{array}{l}\text { Sanitary Ware } \\
\text { (SW) }\end{array}$ \\
\hline $\mathrm{SiO}_{2}, \%$ & 21.5 & 64.4 & 62.2 & 70.8 \\
\hline $\mathrm{Al}_{2} \mathrm{O}_{3}, \%$ & 3.8 & 17.0 & 17.1 & 19.0 \\
\hline $\mathrm{Fe}_{2} \mathrm{O}_{3}, \%$ & 3.8 & 5.6 & 5.7 & 0.9 \\
\hline $\mathrm{CaO}, \%$ & 64.3 & 2.5 & 3.5 & 0.7 \\
\hline $\mathrm{MgO}, \%$ & 0.8 & 1.4 & 1.8 & 0.3 \\
\hline $\mathrm{SO}_{3}, \%$ & 2.6 & - & - & - \\
\hline $\mathrm{Na}_{2} \mathrm{O}, \%$ & 0.1 & 4.2 & 5.2 & 2.7 \\
\hline $\mathrm{K}_{2} \mathrm{O}, \%$ & 1.1 & 2.9 & 2.3 & 4.6 \\
\hline $\mathrm{TiO}_{2}, \%$ & - & 0.7 & 0.7 & 0.3 \\
\hline Loss on ignition $\%$ & 2.1 & 0.6 & 1.0 & 0.6 \\
\hline $\mathrm{C}_{3} \mathrm{~S}, \%$ & 60.0 & \multicolumn{3}{|c|}{ Mineralogical composition } \\
\hline $\mathrm{C}_{2} \mathrm{~S}, \%$ & 16.4 & Quartz & Quartz & Quartz \\
\hline $\mathrm{C}_{3} \mathrm{~A}, \%$ & 3.8 & Feldspar & Feldspar & Mullite \\
\hline $\mathrm{C}_{4} \mathrm{AF}, \%$ & 11.5 & Hematite & Hematite & \\
\hline Gypsum, \% & 5.5 & & & \\
\hline
\end{tabular}


Three DCW originated by different industrial processes were used: mud-brick (MB), industrial ceramic block (CB) and sanitary ceramic ware (SW). DCWs were obtained in coarse aggregate particle size. Their particle size was further reduced to passing 4.75-mm sieve (\#4) and, finally, ground in ball mill until $100 \%$ pass through $75 \mu \mathrm{m}$ sieve $(\# 200)$. For ground DCWs, the Blaine specific surface area (BSS) (23) and the particle size distribution (PSD) were determined. The PSD was determined using Malvern Mastersizer 2000 laser particle size analyzer, and the $\mathrm{d}_{90}, \mathrm{~d}_{50}$, and $\mathrm{d}_{10}$ diameters were calculated. The chemical composition of different ceramic wastes is given in Table 1 and it was determined by Inductively Coupled Plasma Atomic Emission Spectroscopy (ICP-AES) analysis in an external laboratory (ALS, Argentine). The mineralogical composition of DCWs was identified by X-ray diffraction (XRD) and FT-IR spectroscopy (FT-IR). XRD analysis was performed using a Philips PW 3710 diffractometer operating with $\mathrm{Cu}$ $\mathrm{K} \alpha$ radiation at $40 \mathrm{kV}$ and $20 \mathrm{~mA}$ and the FT-IR spectra were performed on NICOLET Magna 500 using $\mathrm{KBr}$ technique.

\subsection{Blended cements}

Nine PBCs were prepared replacing 8, 24 and $40 \%$ of each DCW by mass of Portland cement. The $\mathrm{PBCs}$ are identified using the replacement level and the type of ceramic waste used (CB, MB and SW). Table 2 shows the nomenclature used in this study.

\subsection{Frattini test}

Pozzolanic activity was determined by Frattini test according to the procedure described in EN196-5 at 2, 7 and 28 days (24). This test evaluates the pozzolanic activity of DCW measuring its reaction with the $\mathrm{Ca}(\mathrm{OH})_{2}$ released during the PC hydration. The result is considered positive when the points are located below the calcium hydroxide solubility isotherm at $40{ }^{\circ} \mathrm{C}$.

\subsection{Flow and strength of mortar}

Mortars were made with standard siliceous sand using a sand/cement ratio of 3 and a waterto-cementitious material ratio $(\mathrm{w} / \mathrm{cm})$ of 0.50 . It was mixed using the standard procedure. The

TABLE 2. Nomenclature of PBCs samples

\begin{tabular}{lccc}
\hline & \multicolumn{3}{c}{ Replacement level } \\
\cline { 2 - 4 } Ceramic waste & $\mathbf{8} \%$ & $\mathbf{2 4} \%$ & $\mathbf{4 0} \%$ \\
\hline Industrial ceramic block (CB) & $8 \mathrm{CB}$ & $24 \mathrm{CB}$ & $40 \mathrm{CB}$ \\
Mud brick (MB) & $8 \mathrm{MB}$ & $24 \mathrm{MB}$ & $40 \mathrm{MB}$ \\
Sanitary ceramic waste (SW) & $8 \mathrm{SW}$ & $24 \mathrm{CB}$ & $40 \mathrm{SW}$ \\
\hline
\end{tabular}

workability of mortar was determined using the flow table test according to ASTM C1437 (25). For each mortar batch, the flowability was determined as the diameters of spread mortar measured along four lines in $\mathrm{mm}$. Mortars were cast in $40 \mathrm{x} 40 \mathrm{x}$ $160 \mathrm{~mm}$ specimens moulds and then compacted in two layers, smoothed and covered with plastic sheet to prevent water loss at $20 \pm 2{ }^{\circ} \mathrm{C}$. After $24 \mathrm{~h}$, specimens were removed from the molds and cured in water until the test age. From different blended cements, the compressive strength was determined on prisms at 2, 7 and 28 days. The reported results are the average of six compression tests. The compressive strength index (CS Index) was calculated as the ratio between the compressive strength of the blended cement and the strength of the PC at the same test age.

\subsection{Hydration products}

To study the progress of hydration, blended cement pastes were prepared using a w/ $\mathrm{cm}$ of 0.50 and cured in sealed plastic bags in water-bath at $20^{\circ} \mathrm{C}$ during 2, 7 and 28 days. At this time, fragments of paste samples were carefully ground to particle size lower than $45 \mu \mathrm{m}$ (\#325) and the crystalline hydration phases were identified using XRD analyses.

Determination was performed on Philips PW 3710 diffractmeter operating with $\mathrm{CuK} \alpha$ radiation at $40 \mathrm{kV}$ and $20 \mathrm{~mA}$ using carbon monochromator.

\subsection{Demolition ceramic wastes characteristics}

The XRD patterns and FT-IR spectra od DCWs are shown in Figure 1. The mineralogical composition of the ceramic wastes obtained by XRD (Figure 1-a) includes quartz $\left(\mathrm{SiO}_{2}\right)$, anorthite $\left(\mathrm{CaAl}_{2} \mathrm{Si}_{2} \mathrm{O}_{8}\right)$ and hematite $\left(\mathrm{Fe}_{2} \mathrm{O}_{3}\right)$ for $\mathrm{CB}$ and $\mathrm{MB}$, while $\mathrm{SW}$ is composed by quartz $\left(\mathrm{SiO}_{2}\right)$ and mullite $\left(\mathrm{Al}_{6} \mathrm{Si}_{2} \mathrm{O}_{13}\right)$. The XRD patterns of DCWs show a small but evident diffuse band ranging from 20 to $30,2 \theta$ deg., indicating the presence of amorphous materials (26). According to the XRD data, DCWs contain weak crystalline minerals and amorphous phase. Judged by the XRD diffuse band intensity, the proportion of non-crystalline phases is broader in the SW sample.

FTIR spectra of DCWs (Figure 1-b) confirm the phase identification by XRD. The quartz in all wastes is identified through the strong band at $460 \mathrm{~cm}^{-1}$, corresponding to deformation of Si-O. Stretching bands of $\mathrm{Si}-\mathrm{O}$ are placed at $695 \mathrm{~cm}^{-\mathrm{i}}$ (m), doublet 780-800 $\mathrm{cm}^{-1}$ (s) and $1080 \mathrm{~cm}^{-1}$ (vs) and $1170 \mathrm{~cm}^{-1}$ (s) (27). In addition, CB and MB samples present assignable bands to feldspars (anorthite in this case) at $1100 \mathrm{~cm}^{-1}$ range $(1095$, $948 \mathrm{~cm}^{-1}$ ), which deform and widen the quartz band, and the additional band at $571 \mathrm{~cm}^{-1}$ is also observed. 
The physical characteristics of all materials (density, particle size distribution $-\mathrm{d}_{10}, \mathrm{~d}_{50}$, and $\mathrm{d}_{90^{-}}$and the BSS) are given in Table 3. According to Table 3, three DCW have lower density, larger specific surface area and particle size distribution with large volume ( $\mathrm{d}_{10}$ and $\mathrm{d}_{50}$ are low) of particles, smaller than the corresponding to Portland cement. This is evident for MB and SW samples.
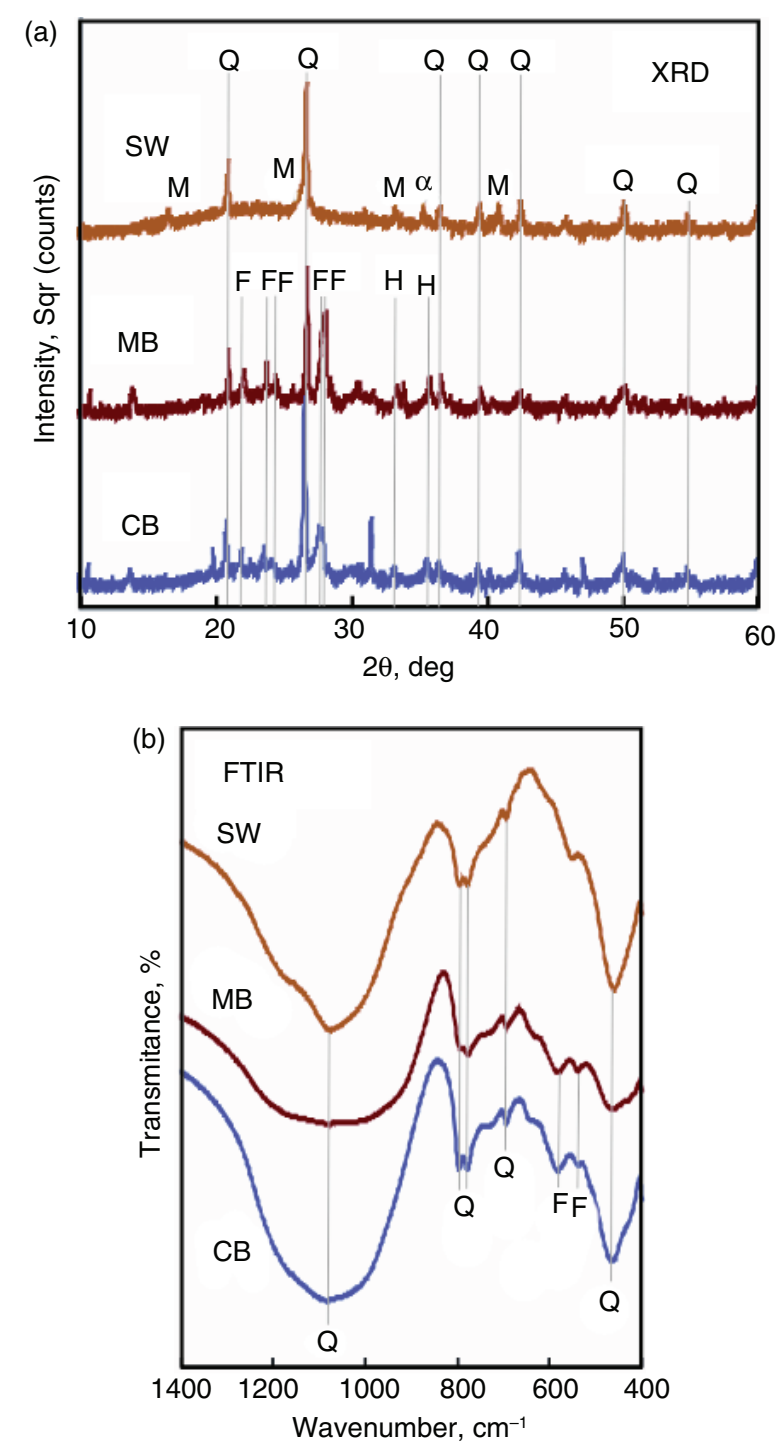

FIGURE 1. Mineralogical composition by DRX and FT-IR methods. Q: quartz, M: mullite, F: feldespar, $\alpha$ : $\alpha$ alumina, H: hematite.

\section{RESULTS AND DISCUSSION}

\subsection{Pozzolanic activity}

Figure 2 shows the results of Frattini test for the PBCs at 2, 7 and 28 days. At 2 days, results for all blended cements were above the calcium solubility isotherm, showing pozzolanic activity did not occur. For the three DCWs, the $[\mathrm{CaO}]$ increased when the level of replacement in blended cement increased, showing the stimulation effect on the hydration of Portland cement phases. In addition, it can be observed that the dilution effect caused by the replacement of $\mathrm{PC}$ by DCWs produced a decrease of $\left[\mathrm{OH}^{-}\right]$when the DCW replacement level increased.

At 7 days, the reduction of $\left[\mathrm{OH}^{-}\right]$and $[\mathrm{CaO}]$ showed that PBCs with high replacement level ( $40 \%$ for all DCWs) have a pozzolanic activity and the test-points are located below the saturation curve. For $24 \mathrm{CB}$ blended cement, the point is on the saturation curve, indicating the early reaction of this DCW. At 28 days, all blended cements presented proper pozzolanic activity.

According to Frattini test results, MB has a slower pozzolanicity than SW, although both have similar specific surface area and particle size distribution.

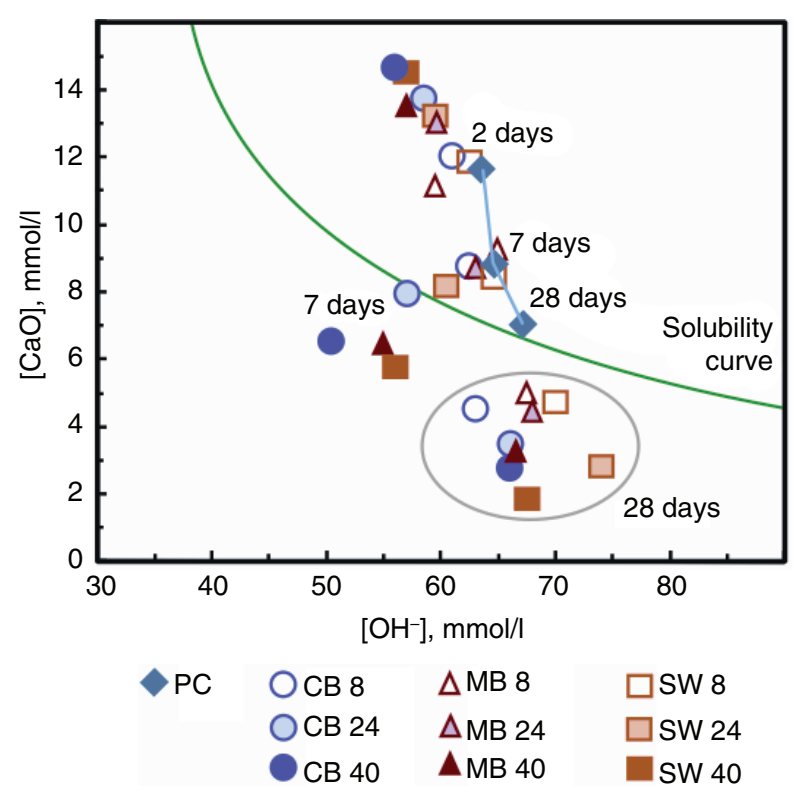

FIGURE 2. Frattini test at 2, 7 and 28 days.

TABle 3. Physical characteristics

\begin{tabular}{lccccc}
\hline Material & $\mathbf{d}_{\mathbf{1 0}}, \boldsymbol{\mu m}$ & $\mathbf{d}_{\mathbf{5 0}}, \boldsymbol{\mu m}$ & $\mathbf{d}_{\mathbf{9 0}}, \boldsymbol{\mu m}$ & Density & $\mathbf{B S S}_{\mathbf{m}} \mathbf{~ m}^{\mathbf{2}} / \mathbf{k g}$ \\
\hline PC & 2.741 & 18.991 & 63.469 & 3.15 & 315 \\
CB & 2.265 & 18.369 & 91.833 & 2.5 & 590 \\
MB & 1.956 & 13.094 & 54.935 & 2.6 & 530 \\
SW & 1.979 & 12.719 & 50.591 & 2.6 & 534 \\
\hline
\end{tabular}


It can be exclusively attributed to the surface characteristics of the particles and the glass content.

\subsection{Flow test}

The results of mortar flow tests for different blended cements are shown in Figure 3. It can be observed that the flow of mortar slightly decreases as the DCW replacement increases in blended cement.

The flow of mortar using $8 \mathrm{CB}(128 \%)$ was approximately the same than that of the control mortar $(\mathrm{PC}=127 \%)$. For mortars $24 \mathrm{CB}$ and $40 \mathrm{CB}$, the flow decreases 14 and $22 \%$ when compared to the control, respectively. For blended cements $8 \mathrm{MB}$ and $8 \mathrm{SW}$, the flow was higher than that of control and their reduction was 3 and $10 \%$ for mortars $40 \%$ MB and 40SW, respectively.

The high flow reduction for CB blended cements is attributable to the large BSS (see Table 3) of this ceramic waste when compared with the specific surface of MB or SW ceramic wastes. For blended cement with low replacement $(8 \%)$, the increase of flow compared with the control mortar may be attributable to the reduction of water fraction used to fill the inter-grains voids due to the better packing of blend that compensates the water needed to wet the large specific surface of DCWs. When the percentage of DCW increases, the flow decreases due to the increase mortar viscosity caused by the high specific surface area and the large volume occupied by solid fraction in paste due to the lower density of DCWs.

\subsection{Compressive strength}

For each ceramic waste, the evolution of compressive strength (CS) of blended cements up to 28 days is shown in Figure 4. Additionally, the figure

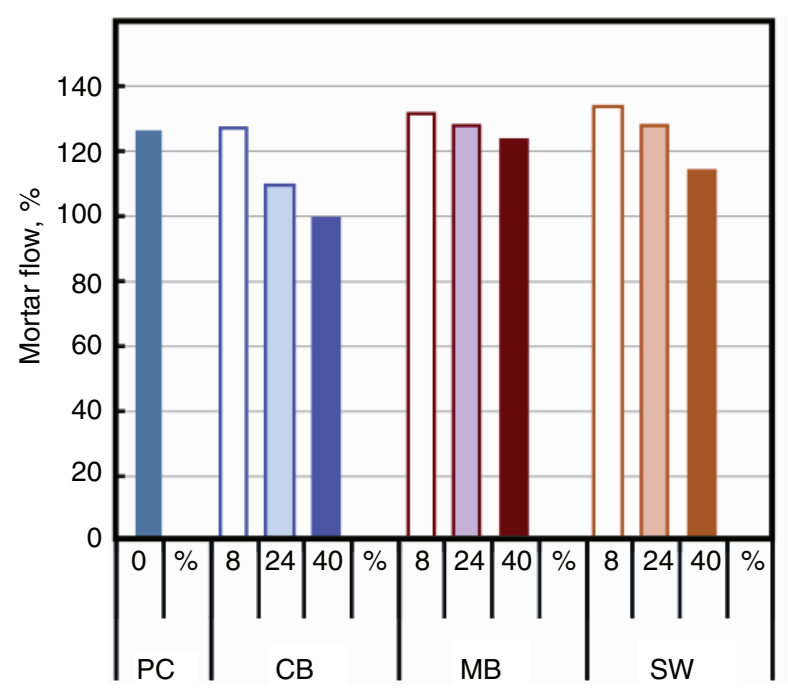

FIGURE 3. Flow of mortars. includes the evolution CS Index. For all DCWs, the compressive strength increases with the curing age and it decreases when the replacement level increases.

At 2 days, CS of all blended cements was less than that of the control mortar and its reduction increased when increasing the replacement level due to the dilution effect caused by the incorporation of ceramic waste. Dilution effect reduces the volume of PC available to react at early age increasing the effective w/c $(0.54,0.66$ and 0.83 for 8,24 and $40 \%$ replacement, respectively) that could not be compensated by the stimulation of PC hydration.

At 7 days, the CS of blended cements with $8 \%$ replacement was similar to that corresponding to PC, indicating that the stimulation of PC hydration compensates the dilution effect. On the other hand, the CS of mortars with $24 \%$ and $40 \%$ of replacement is lower than control, but its reduction is lower than the percentage of DCW replacement.

At 28 days, the CS of blended cement was lower than the control. For 8 and 24\% replacement, the compressive strength is comparable to the control mixture, but it was low for blended cement with $40 \%$ replacement.

For PBCs containing 8, 24 and 40\% DCW, the CS Index was higher than $0.92 ; 0.74$ and 0.60 at 7 and 28 days, respectively. In all cases, the CS Index was higher than the replacement level in the PBCs. At 28 days, the CS index ranged from 0.93 to 1.00 for 8 and $24 \%$ DCW indicating that blended cements could be classified at the same strength class.

\subsection{Hydration at early age, XRD analysis}

The study of the hydration progress of $\mathrm{PC}$ and PBCs by XRD at 2, 7, and 28 days showed a similar behavior. The hydration phases were identical at the same hydration times and the variation of intensity of peaks was only observed due to the different percentages of DCW replacement. As a consequence, Figure 5 only shows the XRD patterns of PC and PBC with $24 \%$ replacement of different ceramic wastes at 2,7 and 28 days.

At 2 days, the PC showed the presence of calcium hydroxide $(\mathrm{CH})$ and ettringite $(\mathrm{Ett})$. In all blended cements, the intensity of Ett and $\mathrm{CH}$ peaks had a similar value to PC despite the dilution effect caused by ceramic addition. These observations reveal that stimulation of PC hydration occurred due to the filler effect, the heterogeneous nucleation and the large amount of free water in the system (28). Quartz (Q) is identified in PBCs from ceramic waste.

At 7 days, the Ett and $\mathrm{CH}$ were accompanied by hemicarboaluminate $(\mathrm{Hc})$, and the incipient formation of monocarboaluminate (Mc). The $\mathrm{Hc}$ and $\mathrm{Mc}$ 

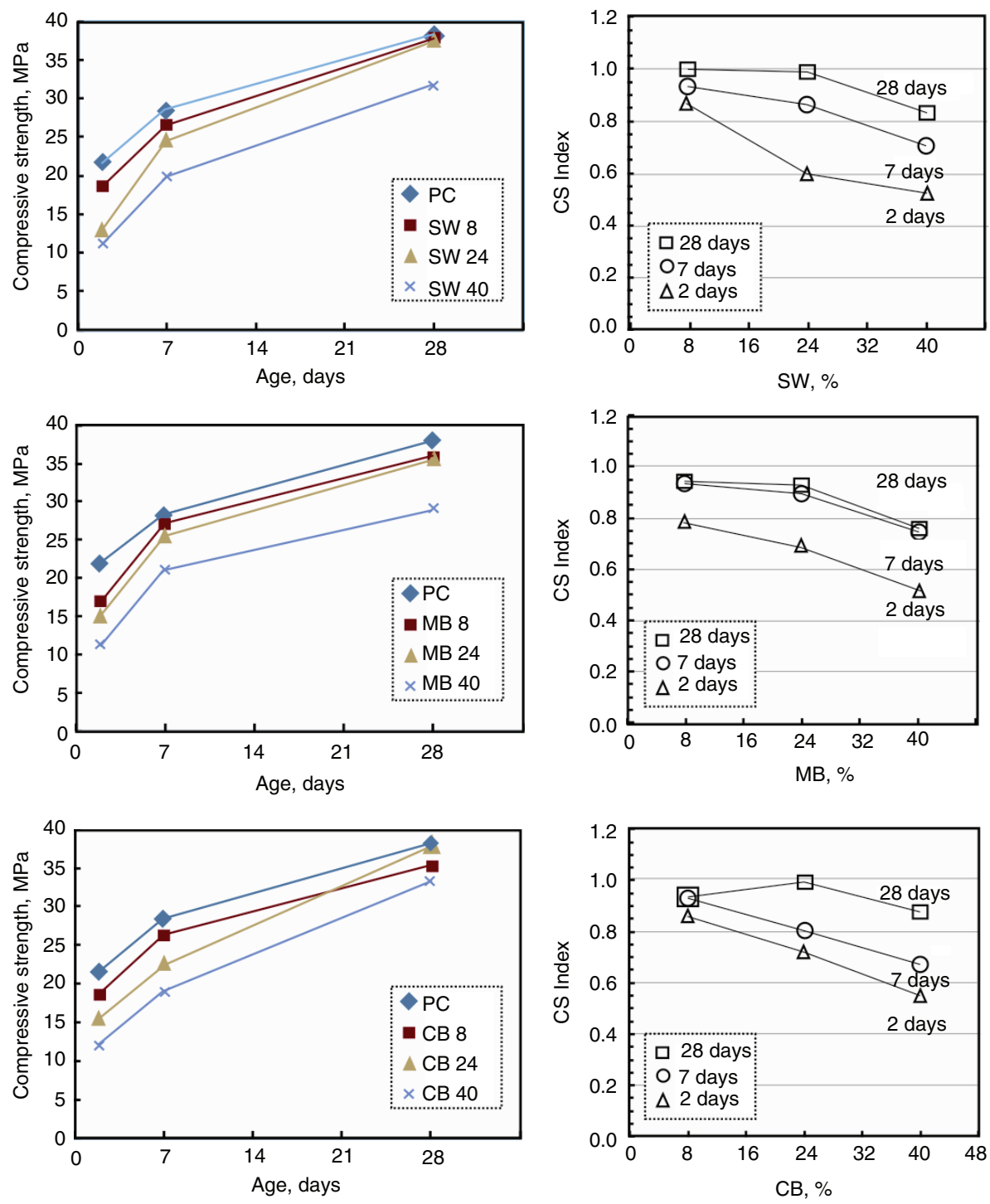

Figure 4. Compressive strength (MPa) and CS Index.

formation was promoted by the calcium carbonate (CC) present in PC as a minor component.

At 28 days, the intensity of $\mathrm{CH}$ and Ett peaks decreased in PBCs. The peak intensity of Mc increased and the intensity of Hc peaks decreased. The reduction of $\mathrm{CH}$ peak was attributed to the pozzolanic reaction generated by the addition of ceramic wastes, according to the Frattini test results. Similar trends were observed for the three materials.

\section{ENVIRONMENTAL BENEFITS}

In addition to the technological properties, the use of DCWs saves a large amount of raw materials and generates other environmental benefits, such as the reduction of energy consumption due to the decrease in grinding time (16), and the reduction of $\mathrm{CO}_{2}$ emissions by ton of $\mathrm{PC}$ with equivalent compressive strength at 28 days for low or medium replacement level (29).

Raw materials for clinker production are primarily based on limestone, clay or its natural mixture. During the clinkering process, the $\mathrm{CaCO}_{3}$ in the limestone is transformed into $\mathrm{CaO}(\mathrm{s})$ and $\mathrm{CO}_{2}(\mathrm{~g})$, the latter being emitted into the atmosphere. Considering the chemical composition of PC used and estimating a complete transformation, $505 \mathrm{~g}$ $\mathrm{CO}_{2}$ by $\mathrm{kg}$ of clinker are emitted due to $\mathrm{CaCO}_{3}$ dissociation, plus approximately $400 \mathrm{~g}$ of $\mathrm{CO}_{2}$ emitted by fuel combustion (30).

Since $\mathrm{CB}, \mathrm{MB}$ and $\mathrm{SW}$ have similar reactivity and considering the replacement level $(8,24$ and $40 \% \mathrm{w} / \mathrm{w}$ ) by ceramic waste, in general, the emission in 72, 216 and $360 \mathrm{~g} \mathrm{CO}_{2} / \mathrm{kg}$ cement could be reduced, respectively. 

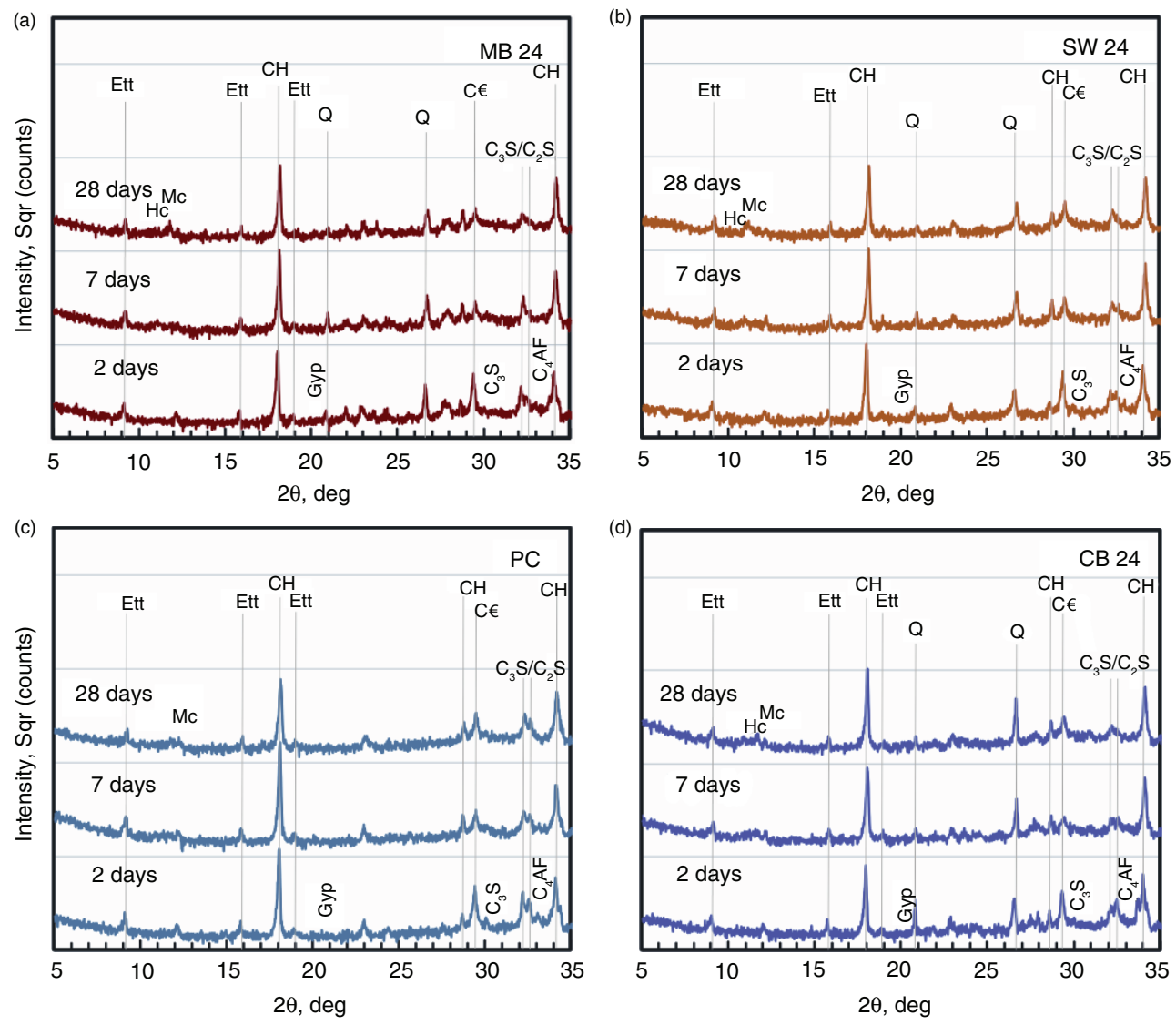

FIGURE 5. XRD patterns of hydration pastes with $24 \%$ of replacement. Q: quartz, CH: calcium hydroxide, Mc: monocarboaluminate, Hc: hemicarboaluminate, Ett: ettringite, CC: calcium carbonate, Gyp: gypsum.

In 2014, according to the Association of Portland Cement Manufacturers in Argentina (AFCP) (31), $11,438,165$ t of cement were exported to the domestic market. Considering that $20 \%$ of the annual production will be carried out with the proposed technology and a replacement of $24 \% \mathrm{w} / \mathrm{w}$ by DCWs, $\mathrm{CO}_{2}$ emissions will be reduced by approximately $3.810^{8} \mathrm{t}$ $\mathrm{CO}_{2} /$ year to obtain the same strength class cement

\section{CONCLUSIONS}

The behavior of three demolition ceramic wastes was analyzed as a partial replacement of PC in the manufacture of PBCs, and the following conclusions were drawn:

- At early ages, the incorporation of ceramic wastes shows the dilution and stimulation of PC hydration due to the increase of effective water to cement ratio in the system and their role as nucleation sites for calcium hydrated products. This can be observed in the Frattini test results at 2 days where the $\mathrm{CaO}$ concentration increases for incremental levels of waste ceramic replacement.
- At later ages, the XRD shows that ceramic wastes incorporation develops its pozzolanic reaction as revealed by the Frattini test and it can be corroborated by the decrease of $\mathrm{CH}$ peaks in XRD patterns at 7 and 28 days. Likewise, the CS Index for blended cements with 8 and $24 \%$ of replacement ranged from 0.93 to 1.00 indicating the pozzolanic contribution of ceramic waste addition to the CS

- The hydration products detected by XRD revealed that hydration mechanisms of PC and the PCBs are the same.

- The experimental results presented here show that ceramic wastes from the construction demolition process have pozzolanic activity. The three DCWs studied have similar reactivity despite their different origins. However, they must be classified as slow pozzolana.

\section{ACKNOWLEDGMENTS}

The authors gratefully acknowledge the financial supports received from the FONCYT, MINCYT Argentine under project PICT 2012-0160. 


\section{REFERENCES}

1. Schneider, M.; Romer, M.; Tschudin, M.; Bolio, H. (2011) Sustainable cement production: present and future. Cem. Concr. Res. 41, 642-650. http://dx.doi.org/10.1016/j. cemconres.2011.03.019.

2. ASTM C618-12a: Standard Specification for Fly Ash and Raw or Calcined Natural Pozzolan for use as a Mineral Admixture in Portland Cement Concrete.

3. Tironi, A.; Trezza, M.A.; Scian, A.; Irassar, E.F. (2012) Kaolinitic calcined clays: Factors affecting its performance as pozzolans. Con. Build. Mat. 28 [1], 276-281. http:// dx.doi.org/10.1016/j.conbuildmat.2011.08.064.

4. Tironi, A.; Trezza, M.A.; Scian, A.N.; Irassar, E.F. (2013) Assessment of pozzolanic activity of different calcined clays. Cem. Concr. Compos. 37, 319-327. http://dx.doi. org/10.1016/j.cemconcomp.2013.01.002.

5. Zimbili, O.; Salim W.; Ndambuki, M. (2014) A review on the usage of ceramic wastes in concrete production. Int. J. Civil, Enviromental, Structural, Construction \& Architectural Engineering 8 [1] 91-95.

6. Andres Juan; César Medina; Julia, M. Morán; M. Ignacio, Guerra; Pedro, J. Aguado; $\mathbf{M}^{\mathrm{a}}$ Isabel Sanchez, De Rojas; Moisés Frías; Olga Rodriguez, 2010. Re-Use of Ceramic Wastes in Construction, Ceramic Materials, Wilfried Wunderlich (Ed.), ISBN: 978-953-307-145-9, InTech, http://www.intechopen.com/books/ceramic-materials/ re-use-of-ceramic-wastes-in-construction.

7. Yuan, H.; Shen, L. (2011) Trend of the research on construction and demolition waste management. Waste Manage. 31, 670-679. http://dx.doi.org/10.1016/j.wasman.2010.10.030

8. Rozas, F.; Castillo, A.; Martínez, I.; Castellote, M. (2015) Guidelines for assessing the valorization of a waste into cementitious material: dredged sediment for production of self compacting concrete. Mater. Construcc. 65 [319], 1-13. http://dx.doi.org/10.3989/mc.2015.10613.

9. Poon, C.S. (2007) Reducing construction waste, editorial. Waste Manage. 27 [12], 1715-1716. http://dx.doi. org/10.1016/j.wasman.2007.08.013.

10. Pereira-de-Oliveira, L.A.; Castro-Gomes, J.P.; Santos, P.M.S. (2012) The potential pozzolanic activity of glass and red-clay ceramic waste as cement mortars components. Con. Build. Mat. 31, 197-203. http://dx.doi.org/10.1016/j. conbuildmat.2011.12.110.

11. Sánchez de Rojas, M.I.; Marin, F.; Rivera, J.; Frias, M. (2006) Morphology and properties in blended cements with ceramic wastes as a pozzolanic material. J. Am. Ceram. Soc. 89 [12], 3701-3705. https://dx.doi.org/10.1111/j. 1551-2916.2006.01279.x.

12. Sánchez de Rojas, M.I.; Marin, F.P.; Frías, M.; Rivera, J. (2007) Properties and performances of concrete tiles containing waste fired clay materials. J. Am. Ceram. Soc. 90 [11], 35593565. http://dx.doi.org/10.1111/j.1551-2916.2007.01944.x

13. Puertas, F.; Garcia-Diaz, I.; Barba, A.; Gazulla, M.F.; Palacios, M.; Gomez, M.P. (2008) Ceramic wastes as alternative raw materials for Portland cement clinker production. Cem. Concr. Compos. 30 [9] 798-805. http://dx.doi. org/10.1016/j.cemconcomp.2008.06.003.
14. Lavat, A.E.; Trezza, M.A.; Poggi, M. (2009) Characterization of ceramic roof tile wastes as pozzolanic admixture. Waste Manage. 29 [5], 1666-1674. http://dx.doi.org/10.1016/j. wasman.2008.10.019.

15. Bignozzi, M.C.; Bondua, S. (2011) Alternative blended cement with ceramic residues: corrosion resistance investigation on reinforced mortar. Cem. Concr. Res. 41[9], 947-954.http://dx.doi.org/10.1016/j.cemconres.2011.05.001.

16. Naceri, A.; Hamina, M.C. (2009) Use of waste brick as a partial replacement of cement in mortar. Waste Manage. 29 [8], 2378-2384. http://dx.doi.org/10.1016/j.wasman.2009.03.026.

17. Lin, K.L.; Chen, B.Y.; Chiou, C.S.; Cheng, A. (2010) Waste brick's potential for use as a pozzolan in blended Portland cement. Waste Manage. Res. 28 [7], 647-652. http://dx.doi. org/10.1177/0734242X09355853.

18. Lin, K.L.; Wu, H.H.; Shie, J.L.; Hwang, C.L.; Cheng, A. (2010) Recycling waste brick from construction and demolition of buildings as pozzolanic materials. Waste Manage. Res. 28, 653-659. http://dx.doi.org/10.1177/0734242X09358735.

19. Binici, H.; Kapur, S.; Arocena, J.; Kaplan, H. (2013) The sulphate resistance of cements containing red brick dust and ground basaltic pumice with sub-microscopic evidence of intra-pore gypsum and ettringite as strengtheners. Cem. Concr. Compos. 34 [2], 279-287. http://dx.doi.org/10.1016/j. cemconcomp.2011.10.001.

20. Ay, N.; Unal, M. (2000) The use of waste ceramic tile in cement production. Cem. Concr. Res. 30 [3], 497-499. http://dx.doi.org/10.1016/S0008-8846(00)00202-7.

21. IRAM 50000: Cement. Cement for general use. Composition, characteristics, conformity assessment and reception (in Spanish).

22. EN 197-1:2011. Ordinary cements: composition, specifications and conformance criteria (in Spanish).

23. ASTM C204-11. Standard test methods for fineness of hydraulic cement by air-permeability apparatus.

24. EN 196-5: Cements Test Methods: Pozzolanic test for Pozzolanic cements (in Spanish).

25. ASTM C1437-15, Standard Test Method for Flow of Hydraulic Cement Mortar-

26. Chakchouk, A.; Trifi, L.; Samet, B.; Bouaziz, S. (2009) Formulation of blended cement: Effect of process variables on clay pozzolanic activity. Con. Build. Mat. 23 [3], 1365-1373. http://dx.doi.org/10.1016/j.conbuildmat.2008.07.015.

27. Bensted, J.; Varna, S.P. (1977) Infrared and Raman spectroscopy in cement chemistry-miscellaneous applications. World Cem. Technol. 8 [1] 16-20

28. Zhang, C.; Wan, A.; Tang, M.; Liu, X. (1996) The filling role of pozzolanic materials. Cem. Concr. Res. 26 [6], 943-947. http://dx.doi.org/10.1016/0008-8846(96)00064-6.

29. Toledo Filho, R.D.; Gonçalves, J.P.; Americano, B.B.; Fairbairn, E.M.R. (2007) Potential for use of crushed waste calcined-clay brick as a supplementary cementitious material in Brazil. Cem. Concr. Res. 37[9], 1357-1365. http:// dx.doi.org/10.1016/j.cemconres.2007.06.005.

30. WRI (2005) Navigating the Numbers: Greenhouse Gas Data and International Climate Policy. World Resources Institute, 74. http://pdf.wri.org/navigating_numbers.pdf

31. http://www.actualizarmiweb.com/sites/afcp/publico/ P201504/estadistica.htm. 